\title{
Critical review of chemical and enzymatic methods for the estimation of nutritive value in roughages
}

\author{
J Aufrère $1, H$ Guérin 2 \\ 1 Station de Recherche sur la Nutrition des Herbivores (SRNH), INRA-Theix, 63122, Saint Genès Champanelle \\ ${ }^{2}$ CIRAD-EMVT-Département d'élevage et de médecine vétérinaire -BP 5035, 2477 avenue du Val de \\ Montferrand, 34032 Montpellier Cedex, France
}

\begin{abstract}
Summary - The methods used classically for estimating the nutritive value of temperate forages (grasses and legumes) have to be corrected to take into account the specificity of roughages (crop residues, numerous tropical species, trees and shrubs), which may affect the results of assays. Tropical forages have their own physical and chemical features linked to genetic factors. For example, they may contain tannins liable to form protein-tannin complexes and to inhibit certain enzymes. In general, the nutritive values of roughages cannot be predicted as accurately as those of temperate forages. For tannin-free temperate and tropical forages, in vivo organic matter digestibility can be predicted by chemical methods based on the determination of cell wall contents or lignin, but these methods are less accurate than enzymatic methods (cellulase). Digestible protein content (DCP) is closely linked to crude protein content $(C P)$ in temperate grassland legumes and in tropical grasses. To determine DCP of tropical herbaceous or woody dicotyledons, cell wall nitrogen (ADIN: acid detergent insoluble nitrogen), which closely corresponds to indigestible nitrogen content, also has to be determined. Tannins, which are present in many dicotyledons, also modify the overall digestibility of nitrogen, but their effects depend on the types of tannins present and on other factors, and are difficult to predict. Prediction of PDI (Protéines réellement digestibles dans l'Intestin grêle, i.e. digestible protein in the small intestine) requires knowing the theoretical degradability of protein in the rumen (Deg) and the true digestibility of dietary proteins (dr) in the small intestine. The methods of Deg prediction using commercially available proteases permit a useful classification of temperate and tropical forages, but must be used carefully especially in tannin-containing forages. Chemical and enzymatic methods of $\mathrm{dr}$ prediction (pepsin-pancreatin) have not been widely used for temperate or tropical forages. Tannin determination provides a qualitative interpretation of differences in the nutritive value between tannin-containing forages. However, none of the numerous methods tested to date can be considered as predictive of the nutritive value. This is partly due to the diversity of the phenol groups present and their methods of determination and to interactions with other digestible nutrients, which makes it difficult to predict the effects of tannins on digestion. For these forages, Van Soest's fractionation corrected for tannin content is a reliable predictive model for energy content, while NDIN (neutral detergent insoluble nitrogen) and ADIN determinations provide an initial approach to degradation mechanisms occurring in the rumen and intestine.
\end{abstract}

\section{Introduction}

Roughages are poor in digestible nutrients, either because nutrients such as nitrogen and non structural carbohydrates are present at low concentrations, or because they are poorly digestible, due to various physical or chemical factors such as lignin and polyphenols.

In warm climates, the diet of many ruminants is largely composed (between 90 and $100 \%$ ) of forages such as the aerial parts of herbaceous mature plants, crop residues after harvest, and trees and shrubs.

As in temperate zones, grasses form the basis of grazing land in humid and subhumid savannah and arid or semi-arid tropical and Mediterranean steppe. Grass straws and cereal straws (maize, sorghum, rice) are also consumed by ruminants in tropical zones.

Legumes are important in pasture ecosystems. They are generally cultivated for maintaining soil fertility and supplementing ruminants diets. Legumes are found among both cultivated and wild herbaceous forage plants, crop plants such as groundnuts and beans, and tree foliage.

Besides these two plant families, browse plants include many other dicotyledon species. 
Table I. Rough forages compared to temperate grasses and legumes. (DM: dry matter, $t \mathrm{~N}$ : total nitrogen, OMD: organic matter digestibility, DCP: digestible crude protein, inDCP: indigestible crude protein, S: solubility, Deg: theoretical degradability).

\begin{tabular}{|c|c|c|c|c|c|c|}
\hline $\begin{array}{l}\text { Examples } \\
\text { Nutritive Value }\end{array}$ & OMD & $\begin{array}{l}\text { DCP } \\
\% \text { DM }\end{array}$ & inDCP & $\underset{\%+N}{S}$ & $\begin{array}{l}\text { Deg } \\
\%+N\end{array}$ & $\begin{array}{c}\text { Condensed } \\
\text { Tannin } \\
\% D M\end{array}$ \\
\hline $\begin{array}{l}\text { Temperate (fresh) } \\
\text { grasses }\end{array}$ & $50-70$ & $5-19$ & 4 & $20-45$ & $65-90$ & \\
\hline Legumes & $55-65$ & $8-20$ & $4-5$ & $7-60$ & $30-90$ & $0-7$ \\
\hline Cereal staws & $35-45$ & 0 & $3-5$ & 35 & 60 & \\
\hline $\begin{array}{l}\text { Tropical grasses } \\
\text { (fresh+standing hay) }\end{array}$ & $45-65$ & $0-12$ & 4 & $20-35$ & $60-65$ & \\
\hline Browse species & $35-65$ & $0-25$ & $4-25$ & $7-67$ & $30-90$ & $0-11$ \\
\hline Oilseed hulls & $15-60$ & $0-12$ & $4-16$ & 20 & $40-55$ & \\
\hline Grape marc & 25 & $0-1$ & $0-1$ & & 15 & $>6$ \\
\hline
\end{tabular}

They contain more nitrogen than grasses, but usually less than legumes. Like legumes, they have variable levels of phenol contents.

Because of their botanical diversity and the pronounced differentiation of their organs and tissues, roughages show considerable morphological, anatomic and physicochemical heterogeneity (table I). This heterogeneity occurs seasonally among plant species, and among organs and tissues. Hence the "rough" characteristics of these forages is neither permanent nor uniform for any particular plant species.

Most of the methods used to predict the nutritive value of forages have been developed in temperate zones, usually for grasses and legumes, in which the range of variation of this value is less wide than in roughages. The composition of these forages usually enables microbial or enzymatic digestion to take place under optimal physiological conditions. In contrast, the specific features of roughages make their digestibility more difficult to measure, and require an adaptation of the prediction methods. In addition, the quality of the estimations is further reduced by differences in the abilities of animal species to use roughages, and the influence of ingestion conditions and other components of diet on digestibility.

After briefly reminding the main features of roughages under poor agronomic conditions, we shall review the adaptations and limits of the chemical and enzymatic methods used to predict their nutritive value.

\section{Differences in chemical composition between temperate forages and roughages in warm climate zones}

This comparison is justified by the fact that our approach involves adapting methods of prediction developed for temperate zone forages.

The first comparison is for grasses for which the genetic and metabolic differences are well known $\left(C_{3}\right.$ versus $C_{4}$ plants).

For the other plant families, the approach is more difficult, since the chemical components that act on digestion are both more numerous and more complex. Their spatial distribution in the tissues and cells and their interactions are also important. However, these data have only been studied for a few species that make up ruminant diets. Comparisons between botanical groups are useful since they can help to extend the scope of the prediction methods.

Only the most marked differences in chemical composition between temperate and warm climate forages will be stated here.

\section{Differences between temperate and tropical grasses}

\section{Cell wall constituents}

Most of the tropical grasses are $\mathrm{C}_{4}$ plants, which fix and concentrate $\mathrm{CO}_{2}$ in 4-carbon organic acids in the mesophyll before photosynthesis, which takes place in the cells of the perivascular sheath. This enables these 
Table II. Leaf attributes of $\mathrm{C}_{4}$, intermediate $\left(\mathrm{C}_{3} / \mathrm{C}_{4}\right)$ and $\mathrm{C}_{3}$ photosynthetic types of Panicum species (According to Wilson et al, 1983).

\begin{tabular}{llllllll} 
Type of & - & Dry matter & Cell wall & \multicolumn{3}{c}{ Tissue proportion in leaf cross-section b } \\
& digestibilty & content & MES & BS & VAS & EPI & SCL \\
Panicum $^{2}$ & $(\%)$ & $(\%)$ & $(\%)$ & $(\%)$ & $(\%)$ & $(\%)$ & $(\%)$ \\
$\mathrm{C}_{4}$ & 69 & 50 & 43 & 20 & 8 & 27 & 1.7 \\
$\mathrm{C}_{3} / \mathrm{C}_{4}$ & 70 & 42 & 48 & 18 & 6 & 26 & 1.7 \\
$\mathrm{C}_{3}$ & 76 & 33 & 66 & 10 & 3 & 22 & 0.5
\end{tabular}

aMeans of $18\left(C_{4}\right), 3\left(C_{3} / C_{4}\right)$ and $6\left(C_{3}\right)$ Species; bMES, mesophyll; BS, bundle sheath; VAS, vascular bundle; EPI, epidermis; SCL, sclerenchyma.

plants to save water through more efficient use and to grow more rapidly in high ambient temperatures than temperate $\mathrm{C}_{3}$ grasses. Conversely, at low temperatures, including in altitude or during the cool period in certain tropical regions, the growth rates of $\mathrm{C}_{4}$ plants are lower than those of $\mathrm{C}_{3}$ plants.

The $\mathrm{C}_{4}$ grasses are richer in cell wall material, but also have more tissues that are poorly digestible or less readily digestible than in $\mathrm{C}_{3}$ plants (epidermis, sclerenchyma, perivascular parenchyma and vascular bundle), as shown by Wilson et al (1983) in the genus Panicum (table II).

Under unrestricted water supply conditions, high temperatures accelerate ageing of tropical grasses. This can be measured in terms of stem growth compared to leaf growth, and chemical differentiation as expressed in their cell wall constituents (lignocellulose).

The poorer digestibility of tropical grasses results therefore from the fact that they are mainly $\mathrm{C}_{4}$ type plants and that they grow at higher temperatures than temperate $C_{3}$ grasses.

Other cell wall constituents contribute to the poor digestibility of the cell walls of tropical grasses, for example the silica that coats the epidermis of rice stems and leaves, and the cutin (Van Soest, 1994).

\section{Digestibility}

On average, wild or cultivated tropical grasses have lower dry matter digestibilities (DMD) than temperate grasses. During active plant growth the difference can reach 10 to 15 points ( 55 to $65 \%$ versus 60 to $80 \%$ ) (INRA, 1989). Over 6 to 9 months of the year in dry tropical zones when tropical forage grasses are not growing, steppe annual grasses and savannah perennial grasses have digestibilities comparable to those of rice and sorghum straws (DMD close to $50 \%$ ) and those of wheat and barley straws (DMD close to $40 \%$ ),

Table III. Typical concentrations of carbohydrates in temperate legumes, and cool and warm -season grasses (adapted from Van Soest, 1982, according to Moore and Hatfield, 1994).

\begin{tabular}{lcll} 
Category & $\begin{array}{c}\text { Temperate } \\
\text { Legumes }\end{array}$ & $\begin{array}{l}\text { Cool-Season } \\
\text { Grasses }\end{array}$ & $\begin{array}{l}\text { Warm-Season } \\
\text { Grasses }\end{array}$ \\
$\begin{array}{l}\text { Nonstructural Carbohydrates } \\
\text { Soluble sugars }\end{array}$ & $\left.\mathrm{kg}^{-1} \mathrm{DM}\right)$ & & \\
Starch & $20-50$ & $30-60$ & $10-50$ \\
Fructans & $10-110$ & $0-20$ & $10-50$ \\
Structural carbohydrates & $\left(\mathrm{g} \cdot \mathrm{kg}^{-1} \mathrm{DM}\right)$ & $30-100$ & - \\
Cellulose & $200-300$ & & \\
Hemicellulose & $40-170$ & $150-450$ & $220-400$ \\
Pectin & $40-120$ & $120-170$ & $250-400$ \\
\hline
\end{tabular}


respectively (Richard et al, 1989)

\section{Cell contents}

- Cytoplasmic carbohydrates

The levels of water soluble carbohydrates such as glucose, fructose and sucrose in tropical grasses are generally low compared to those in temperate zone grasses ( 3 to $5 \%$ and 6 to 10 $\%$ DM respectively). Their polyhoside reserve is starch, which is mainly stored in the leaves (2 to $5 \% \mathrm{DM}$ ), whereas temperate meadow grasses mainly store fructosanes in stems and sheaths (2 to $10 \%$ DM), (table III).

-Nitrogen

During early growth, tropical grasses contain slightly less nitrogen than temperate grasses (2.5 to $4.0 \% \mathrm{DM})$, but in tropical grasses, nitrogen content decreases more rapidly with age of plant. At the end of the growth cycle, the nitrogen content may be very low ( $0.5 \% \mathrm{DM})$. This difference relative to temperate grasses partly derives from the faster growth of tropical zone grasses, with an increase in the proportion of stems and the senescence of leaves, together with generally low levels of soil nitrogen.

The nitrogen of cell walls represents a small part of total nitrogen. Plant proteins can be mainly split into two groups according to their location in the plant tissue : the watersoluble proteins of the cytoplasm and the water-insoluble proteins of the inner membranes of the chloroplasts. Wherever they are located, these proteins are not accessible until the cell membrane or cell wall polysaccharides have been hydrolysed. The proportion of proteins released therefore depends on the accessibility of the chlorophyll tissue to the rumen micro-organisms.

The solubility of nitrogen in a phosphate buffer at pH 6.9 (Vérité and Demarquilly, 1978) is on average 0.30 for temperate grasses versus 0.24 for tropical grasses (Richard, 1987). These means hide very large differences between organs in tropical grasses through organ differentiation and selection by animals. Aii and Stobbs (1980) have found values ranging between 0.15 and 0.43 according to the species, the organ and its growth stage, i.e. an average of 0.28 , but they used a slightly different buffer (Burroughs mineral solution).

Soluble proteins are distributed differently in tropical $\mathrm{C}_{3}$ and temperate $\mathrm{C}_{4}$ grasses. Ribulose 1,5-diphosphate carboxylase makes up 30 to $80 \%$ of the soluble proteins in $\mathrm{C}_{3}$ grasses versus $10-20 \%$ in tropical $\mathrm{C}_{4}$ grasses (Huffaker, 1982). The different distribution of these proteins in temperate grasses (in the mesophyll) and tropical grasses (in the perivascular sheath) (Wilson, 1994) may partly explain the differences in the nitrogen
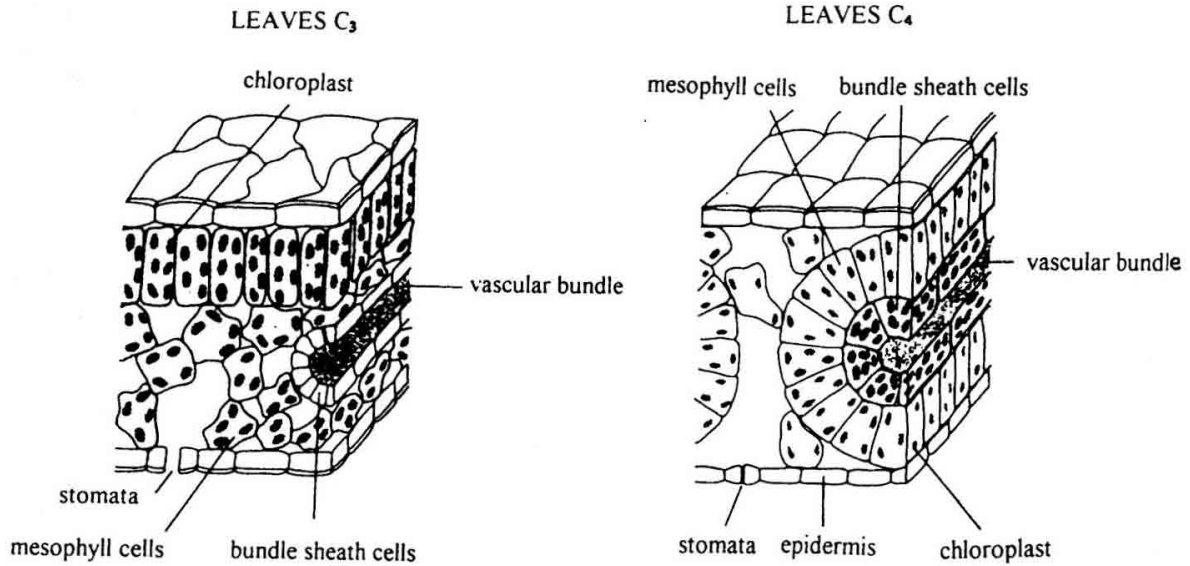

Figure 1. Anatomical comparison between $\mathrm{C}_{3}$ leaves and $\mathrm{C}_{4}$ leaves (according to Alberts et al, 1990). 
degradability of these forages (Redfearn et al, 1995) (figure 1). Moreover the chloroplast membrane proteins of temperate grasses are poorly soluble as they are complexed with chlorophyll, but those of tropical grasses are even less soluble.

\section{Comparison of tropical dicotyledons and temperate grasses and legumes}

\section{Cell wall constituents}

Compared to grasses, dicotyledons are characterised by average total cell wall contents (Neutral Detergent Fibre, abbreviated NDF) that are lower but which vary widely among species. In contrast, lignin contents are often higher, but at equal lignin levels, the dicotyledons are more digestible than the grasses. Legumes for instance are less rich in cell wall material, and the composition and structure of their lignin are different resulting in a lower effect on cell wall digestibility (figure 2). In grasses the lignin contains more ester bonds and more readily hydrolysable methoxyl groups than that of dicotyledons, which have more ether bonds (Lapierre et al, 1989)

Lignin levels in tropical herbaceous dicotyledons are slightly higher ( 7 to $14 \%$ DM) than in the usually cultivated legumes including lucerne and clover (7 to $10 \%$ ). Lignin levels in shrub forages vary widely (on average $13 \pm 6.5 \%$ DM on 700 samples of tropical tree foliage). Given the complexity of lignins, the poor accuracy of ADL (Acid Detergent Lignin) determinations and possible contamination (Maillard reactions, tannins, etc...), the highest values (up to $40 \%$ DM) are to be considered with caution.

\section{Nitrogen}

In dry periods, when no young grass is growing, herbivores find their nitrogen supply in herbaceous or shrubby dicotyledons. Whether green or dry, these offer organs, i.e. chlorophyll stems, folioles, inflorescences, fruit and seeds, which are richer in nitrogen ( 1 to $5 \% \mathrm{DM}$ ) than grass straws. To an even larger extent than in grasses, this nitrogen is variably distributed between cell walls and cytoplasm and for the cytoplasmic fraction between soluble and insoluble proteins.

In certain dicotyledons, especially in tropical woody species, part of the proteins binds to tannins during ingestive mastication to form complexes of varying stability, making this

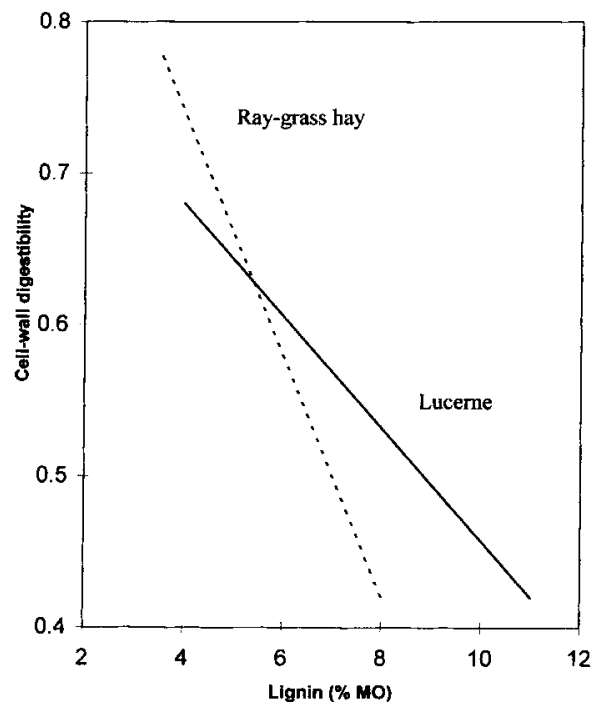

Figure 2. Relationship between cell-wall digestibility and lignin content (according to Jarrige, 1981).

nitrogen partly unavailable to the animal.

Though relatively abundant, the nitrogen in these forages thus exhibits varying digestibility due to physical and chemical factors. The methods for predicting the nitrogen value must therefore directly take into account nitrogen unavailability in the rumen or intestine, or estimate it by characterising the physical and chemical factors that are responsible.

Antinutritional factors and toxic constituents Many substances synthesised by plants and released during mastication serve to protect them against herbivores by making the plant material less appetising (e.g., astringent effects of tannins), or even toxic. Polyphenols (including tannins) are the most common of these substances. Legumes in tropical zones contain other toxic substances such as lectins, protease inhibitors, nonprotein amines, gums, alkaloids and some amino acids (i.e. mimosine in Leucaena leucocephala). This toxicity depends on the amounts ingested and their metabolism and restricts the use of certain forage species, even though they can have high energy and/or nitrogen values (Manidool, 1983; D'Mello, 1992). 
Tannins are complex phenolic polymers capable of precipitating proteins. Tannins are especially abundant in certain legumes (e.g., sweet clover, sainfoin, desmodium) and in many tree and shrub species. They are classified into condensed tannins and hydrolysable tannins.

Condensed tannins are polymers with a flavone nucleus and high molecular weights $(1000$ to 30000$)$. They are present in the vacuoles of a network of specialised cells situated under the epidermis of the leaves and stems of some temperate herbaceous, tropical herbaceous and shrub legumes, and in the leaves of forage shrubs in semi-arid zones.

As soon as the cell structures are destroyed by mastication, the condensed tannins can bind to soluble proteins such as ribulose 1,5-diphosphate carboxylase, by hydrogen linking in particular (Jones and Mangan, 1977). These complexes are stable at the $\mathrm{pH}$ of the rumen, but dissociate to some extent at the acid $\mathrm{pH}$ in the abomasum and at the alkaline $\mathrm{pH}$ in parts of the small intestine, releasing some proteins, as shown in figure 3 . They may therefore be beneficial to the animal by reducing protein degradation in the rumen without adversely affecting true protein digestibility in the intestine. This beneficial action will persist as long as the condensed tannin content does not exceed $4 \%$ of the dry matter (Barry et al, 1986; Mangan, 1988). However, at higher levels, the quantity of tannins present may exceed the amounts of protein available for binding and may then inhibit some microbial or digestive enzymes, or bind to cellulose, protecting it partially from degradation in the rumen.

The hydrolysable tannins have lower molecular weights (500 to 3000$)$ and precipitate proteins less readily than condensed tannins. They are partly hydrolysed in the digestive tract, and can be toxic if ingested in large amounts. A feed content of $20 \%$ will cause acute poisoning in steers and sheep (Reed, 1995). Hydrolysable tannins can reduce cell wall degradation in the rumen and be hydrolysed in the intestine, releasing substances that are toxic for the liver and kidneys (McLeod, 1974).

Total phenolic substances make up only 1.5 to $2.5 \% \mathrm{DM}$ in some meadow grasses in temperate regions, but much more in some temperate dicotyledons ( 3 to $6 \%$; Scehovic, 1990 ) and up to $10 \%$ or more in some tropical forage shrubs (Ahn et al, 1989).

Tannins modify nitrogen and organic matter digestibility at all stages of digestion. It is therefore important to determine their content. However, the results of the

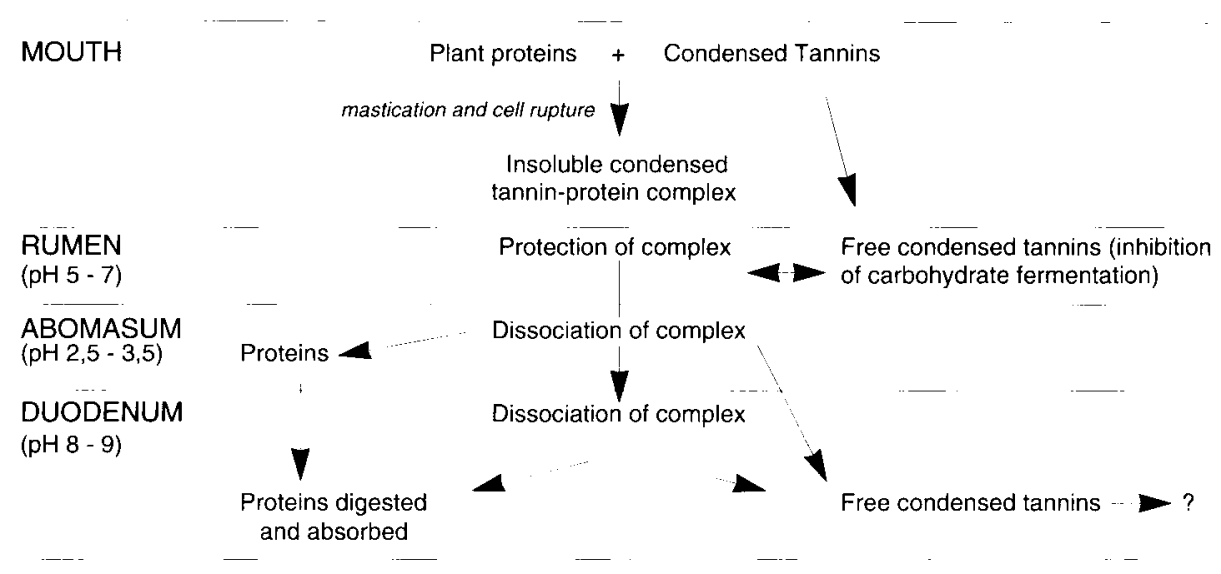

Figure 3. Condensed tannins and protein protection in the rumen (according to D'Mello, 1992). The protein-condensed tanin complex escapes fermentation in the rumen where the $\mathrm{pH}$ ranges from 5 to 7 but dissociates on exposure to gastric $(\mathrm{pH} 2,5-3)$ and pancreatic $(\mathrm{pH} 8-9)$ secretion. 
determinations are difficult to interpret due to the numerous factors involved in the action of tannins.

\section{Prediction of energy value}

The prediction of the energy value, expressed in net energy (NE) or metabolizable energy (ME) usually consists in estimating the organic matter digestibility (OMD), which is the main factor of variation in the energy value.

The methods used to predict OMD basically consists in defining mathematical relationships to link in vivo digestibility with the results of chemical or enzymatic laboratory tests.

The in vivo digestibility of roughages depends on their specific characteristics, but also on the conditions in which they are used. Forages poor in fermentable nitrogen and in certain minerals such as $\mathrm{P}, \mathrm{Mg}, \mathrm{S}$ and $\mathrm{Cu}$ have to be supplemented so that the rumen can function correctly and these forages reach their full «potential» digestibility. Roughages are usually associated with other feeds in animal diets, and numerous interactions can therefore take place. Forages containing tannins have in vivo digestibilities that depend on their proportion in the diet. Moreover, samples taken for analysis usually correspond to the forage "offered", whereas in vivo digestibility correspond to the forage "ingested", whose chemical composition is different due to the choice made by the animal. This difference is more marked for roughages, and depends on the amount of feed on offer (refusal rate) by the experimenter or farmer. This partly accounts for the lower accuracy of prediction of the digestibility of these forages compared to those of temperate zones using laboratory methods.

The choice of diets, the in vivo digestibility measurements of which act as a reference, must be chosen taking into account these factors. However, since (i) it is difficult to make in vivo measurements on many plant species under all conditions of use, and (ii) it is often enough to study relative values of the forage nutritive value, the digestibility of reference samples is sometimes determined in vitro (Tilley and Terry, 1963, Menke et al, 1979), or in situ (Demarquilly and Chenost, 1969).

The cytoplasmic constituents of forage grasses and legumes in temperate zones have a true digestibility of practically $100 \%$. The non cell wall constituents such as nitrogen and lipids, recovered in faeces are essentially of endogenous or microbial origin, and their quantities vary slightly as a function of the dry matter intake (DMI) - $120 \mathrm{~g}$ to $140 \mathrm{~g}$ faecal organic matter per kg DMI (Demarquilly and Jarrige, 1981). A relationship was established by Van Soest (1967) from 18 hays.

$$
\begin{aligned}
& \mathrm{SD}=0.98 \times \mathrm{S}-129 \quad \mathrm{R}=0.99 \\
& \mathrm{SD} \text { : soluble digestible }(\mathrm{g} / \mathrm{kg} \mathrm{DM})
\end{aligned}
$$

$\mathrm{S}$ : soluble $=1000-\mathrm{NDF}$ (g/kg DM)

The amount of apparently indigestible OM found in faeces thus mainly depends on the amount of indigestible cell wall ingested. For these temperate forages, predicting OMD requires predicting the cell wall indigestible content, which highly depends on the amount and nature of the lignin contained in these cell walls.

In contrast, for some forages, especially those rich in tannins and other often badly known secondary compounds, the true digestibility of the cytoplasmic constituents is not total, but highly variable according to the amounts and nature of these secondary compounds. In addition, the digestibility of the cell walls of these forages is also affected by tannins.

The OMD of these forages does not therefore only depend on their indigestible cell wall content, which is highly variable, but also on their concentrations in truly indigestible cytoplasmic constituents.

\section{Prediction of OMD by chemical methods}

\section{Nitrogen}

Crude protein content (CP) is often a good predictor of OMD in both temperate and tropical grasses, since it diminishes as the plants growth and age, and also varies inversely with the indigestible cell wall fraction. However, OMD predictions are only accurate if they are carried out on individual plant species, production cycles or seasons, and soil types. The nitrogen content of grasses depends directly on the nitrogen supply from the soil they are growing on, which can be a limiting factor in tropical zones. Wide variations in $\mathrm{CP}$ for the same digestibility can be observed within the same species (Guérin, 1987).

Conversely, for most dicotyledons in tropical zones, total nitrogen is a poor predictor of OMD (Guérin, 1987). 


\section{Crude fibre}

Cell wall indigestibility is mainly due to the lignin content. However, the Weende crude fibre values in temperate forages increase according to the cell wall content, at least in the course of any given growth cycle. Therefore crude fibre is generally a good criterion of cell wall indigestibility for a particular plant. However, for the same crude fibre content, plants can exhibit different digestibilities according to the plant species and, even, to the regrowth cycle number. Crude fibre content (CF) will therefore permit digestibility to be accurately predicted only if equations specific to each species are used. Prediction is improved if nitrogen content is included in the prediction equation (Andrieu and Weiss, 1981).

However, determination of CP and CF does not solve the problem of predicting the digestibility of mixed forage or forage of permanent pasture, since specific equations would be required for each case, which is impracticable.

For hay harvested at the end of its first cycle, straws, and old tropical forages in which crude fibre varies relatively little, it is preferable to use lignin content to estimate OMD.

\section{Cell wall constituents}

Van Soest's fractionation (Van Soest and Wine, 1967) makes it possible to measure the total cell wall content (neutral detergent fiber, NDF), lignocellulose content (acid detergent fiber, ADF) and lignin content (acid detergent lignin, $A D L$ ) of forages. In particular, ADF determination allows the evaluation of practically all the cellulose and lignin. For a given species and organ, the relationship between ADF and total crude fibre is usually high, which allows forages analysed by different methods to be compared.

This fractionation also permits an estimation of the degree of cell wall lignification from the ADL/NDF and ADL/ADF ratios. This is one advantage of Van Soest's method over that of Wende, since these ratios vary widely from one browse species to another.

To predict the digestibility of forages, total cell wall content or NDF is a less accurate predictor of OMD than ADF or crude fibre. Lignin content is the variable most closely linked to in vivo digestibility, at least when correctly determined. This is even more obvious for predicting OMD of forages from different species or cycles but belonging to the same botanical families. It is necessary to establish separate relations, at least for grasses and legumes. For the same lignin content, legumes have less indigestible cell wall material and higher digestibility than grasses (Van Soest, 1964; Demarquilly and Andrieu, 1987). The parameters NDF, ADF, ADL have been associated in models which take into account cell wall content and lignification. The summative equations of Goering and Van Soest (1970), for example, offer the advantage of being both accurate and applicable to wide ranges of forages:

$\mathrm{DDM}=0.98 \times \mathrm{S}+\mathrm{NDF} \times[147.3-78.9$ $\left.\log _{10}[(L / A D F) \times 100]\right]-M$

where: $D D M=$ digestibility of dry matter in percent; $\mathrm{S}=$ cell content of average digestibility $98 \% ; L=$ acid detergent Klason lignin, $\mathrm{M}=$ estimation of faecal metabolic losses (12.9 units on average for sheep).

However, this analytical procedure is still imperfect for several reasons :

(i) In legumes, the neutral detergent solution used to determine NDF solubilises pectic substances present in stems at levels between 11 and $22 \%$ (Hatfield, 1992). The cell wall content is thus underestimated. This is of little consequence in grasses, in which the levels of these pectic substances are very low ( 1 to 2.5 $\%)$. For the purposes of predicting digestibility, this underestimation is of limited consequences since the pectic substances are highly digestible.

(ii) Cell wall content (NDF and ADF) can be overestimated if a large proportion of nitrogen remains bound to the cell walls, which is the case in temperate zone forages for legumes, young grass leaves, (Van Soest and Robertson, 1980), and numerous tropical dicotyledons (Guérin et al, 1989). In addition, tropical dicotyledons can contain large amounts of cutins and tannins that form insoluble complexes with neutral and acid detergent solutions (figure 4). The presence of varying quantities of tannins can lead to an overestimation of lignocellulose content (Makkar et al, 1995). Van Soest's fractionation is not suitable for forages containing tannins, though more recently a summative equation corrected for tannin content has been proposed (Conklin et al, 1987). Although prediction is improved, it is still often poor. A specific equation would be needed for each plant species and even each organ, given the diversity of the nature of the tannins and their 


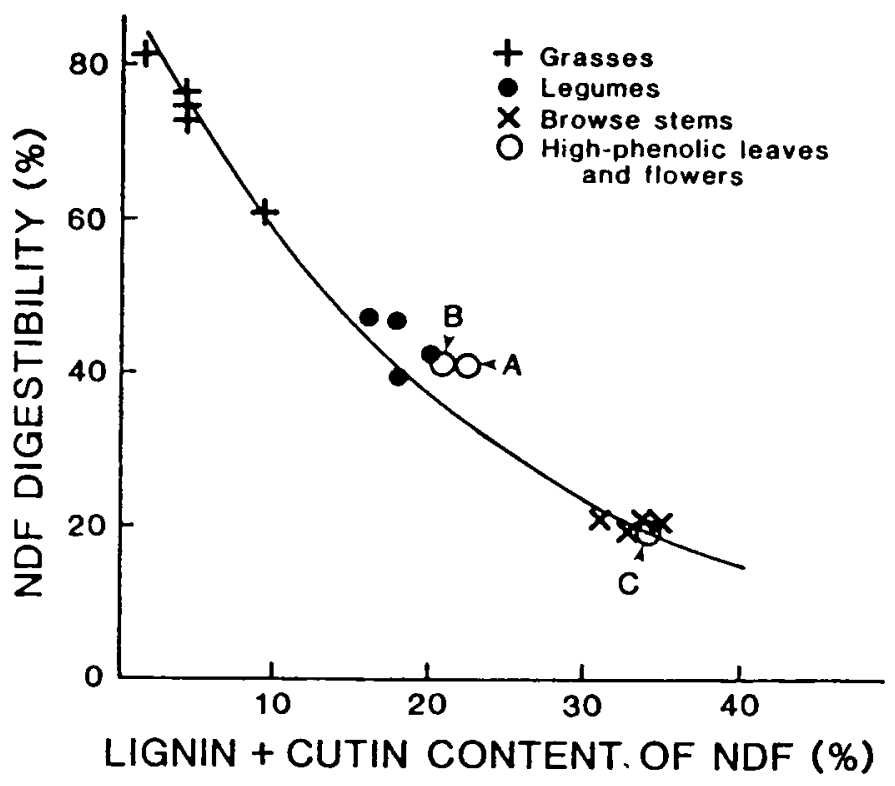

Figure 4. Digestibility of neutral detergent fiber (NDF) fed to mule deer and white-tailed deer as a function of the fiber's lignin and cutin content (according to Robbins et al, 1987).

High-phenolic forages are (A) red alder leaves (B) red-osier dogwood leaves, and (C) fireweed flowers.

levels according to the plant species, organ and growth stage.

(iii) The results of $A D L$ determinations can be adversely modified by errors caused by products of Maillard reactions (Van Soest and Mason, 1991) or by tannins (Van Soest, 1994). These errors can be important, and ADL is certainly overestimated, like in shrub forages (ADL $40 \%$ of DM).

Acid detergent insoluble nitrogen (ADIN) is essentially made up of nitrogen of extensin and enzymes in the primary cell wall (peroxidases). It represents 7 to $9 \%$ of total nitrogen. We can add the nitrogen implicated in the Maillard reactions, and that of the proteins complexed by the tannins. ADIN levels above $9 \%$ of total nitrogen thus indicate indigestibility factors.

Regardless of its origin, ADIN indicates the general level of indigestibility factors that are often especially important in roughages. This explains why ADIN is a more efficient predictor of OMD than total nitrogen or ADF for tropical zones forages that are usually of varying composition (Guérin et al, 1988 ; SilvaColomer et al, 1989).
Van Soest's fractionation does not lead to the isolation of perfectly pure chemical entities, but it offers the advantage of being rapid, reproducible and can be automated for samples poor in proteins, tannins, lipids and/or starch. Other more accurate methods (method of Jarrige, 1961, determination of phenolic acids) may be used, but these are often time and money consuming. However, whatever the fractionation method used, the digestible and indigestible fractions are not separated as they are by in vitro, in situ and enzymatic methods.

\section{Prediction of $O M D$ by enzymatic methods}

The specificity and advantage of ruminal digestion are mainly linked to the cellulolytic activity of the microbial flora. In the 1960's, Donefer et al (1963), Jarrige and Thivend (1969) used commercially available cellulolytic enzyme preparations, often extracted from fungi, to reproduce this activity. Since then, many enzymatic methods have been proposed to predict feed digestibility. They differ in the nature of the enzyme preparations and 
Table IV. Prediction of organic matter digestibility (percentage) by using chemical and enzymatic methods.

\begin{tabular}{|c|c|c|c|c|}
\hline Nature of samples & $n$ & Method used* & RSD & Reference \\
\hline Temperate forages & & crude fibre & 2 to 6 & review of Giger-Reverdin, 1995 \\
\hline Temperate forages & & crude fibre, MAT & 2 (species) & Andrieu and Weiss, 1981 \\
\hline Temperate forages & & ADF & 1.6 to 5.3 & review of Giger-Reverdin, 1995 \\
\hline Temperate forages & & pepsin-cellulase & 1.4 to 3.5 & $\begin{array}{l}\text { review of Aufrère and } \\
\text { Michalet-Doreau, } 1990\end{array}$ \\
\hline Tropical forages & 45 & pepsin-cellulase & 2.7 & Goto and Minson, 1977 \\
\hline Tropical forages & 30 & $\mathrm{ADL}$ & 6.9 & Kronauer and Bickel, 1981 \\
\hline Tropical forages & 10 to 27 & $N, A D F$ & 2.7 to 3.8 & Guerin et al, 1989 \\
\hline Tropical hays & $\begin{array}{l}23 \\
23\end{array}$ & $\begin{array}{l}\text { CB, MAT } \\
\text { pepsin-cellulase }\end{array}$ & $\begin{array}{l}7.2 \\
4.5\end{array}$ & $\begin{array}{l}\text { Zoungrana, } 1995 \\
\text { idem }\end{array}$ \\
\hline Untreated straw & $\begin{array}{l}36 \\
36\end{array}$ & $\begin{array}{l}\mathrm{ADL} \\
\text { pepsin-cellulase } \\
\text { (selon Rexen, 1977)) }\end{array}$ & $\begin{array}{l}2.3 \\
2.7\end{array}$ & $\begin{array}{l}\text { Demarquilly and Andrieu, } 1987 \\
\text { idem }\end{array}$ \\
\hline Ammonia treated straw & $\begin{array}{r}55 \\
55\end{array}$ & $\begin{array}{l}\text { NDF, MAT, Phenols } \\
\text { pepsin-cellulase } \\
\text { (selon Rexen, 1977) }\end{array}$ & $\begin{array}{l}2.8 \\
4.1\end{array}$ & $\begin{array}{l}\text { Guillermin et al, } 1988 \\
\text { idem }\end{array}$ \\
\hline
\end{tabular}

"MAT: Matière Azotée Totale; ADF: Acid Detergent Fiber; ADL: Acid Detregent Lignin; N: Nitrogen; CB: Cellulose Brute; NDF: Neutral Detergent Fiber.

whether a pre-treatment is necessary or not (chemical or enzyme) (Aufrère and MichaletDoreau, 1990). These methods are widely used for forages, and have also been applied to by-products, concentrate and mixed feeds produced by agro-food industry. For various types of forages, in temperate or tropical zones, prediction is higher than with chemical methods (table IV) and comparable to that obtained in vitro (Terry et al, 1978; Aufrère and Demarquilly, 1989; Navaratne et al, 1990). In addition, cellulase methods can be used for mixtures and permanent pastures. They also offer the advantage of measuring improvement in the digestibility of hays and straws treated with ammonia, unlike the usual chemical methods. For these forages, which have low cell contents, a simplified method can be applied, with no pre-treatment (Rexen, 1977). For straws, however, different equations must be used according to whether they are treated or not (Table IV).

For forages containing tannins, OMD prediction is poor when cellulolytic enzymes are used. Two possible reasons can be suggested for this: (i) The enzymes are used at $\mathrm{pH}$ values different from that prevailing in the rumen, enabling possible release of tannins bound to proteins. The diagram of Mangan (fig 3 ) shows the varying degrees of reversibility of the protein complexation according to the $\mathrm{pH}$ of the digestive compartment. Tannin-protein bonds favoured at the rumen $\mathrm{pH}(5$ to 7$)$ dissociate at $\mathrm{pH}$ values outside the range 4 to 7 . In the pepsin-cellulase method, for example, pepsin pre-treatment $(\mathrm{pH}$ approx. 3) could cleave protein-tannin complexes and lead to an overestimation of OMD for these forages.

(ii) Some kinds of tannins might have inhibiting effects on the enzyme activity, especially that of cellulases (Smart et al, 1961; Mandels and Reese, 1963).

However, for tree foliage species with or without tannins, pepsin-cellulase digestibility is closer to in vitro digestibility than chemical criteria in general, though its accuracy is very poor (about 6 points) (table $V$ ). Both enzymatic and chemical methods lead to satisfactory accuracy only if the different species are taken separately.

Besides their ease of use, and their favou- 
Table V. Use of chemical and pepsin-cellulase methods to predict in vitro organic matter digestibility (in vitro OMD) of browse leaves (Steingass and Arbelot, 1994).

\begin{tabular}{|c|c|c|c|c|c|}
\hline & $\mathrm{n}$ & $\begin{array}{l}\text { In vitro digestibility } \\
\text { (gaz-test method) } \\
\text { mean value }\end{array}$ & laboratory methods* & $\mathrm{R}^{2} \mathrm{H}$ & \\
\hline \multirow[t]{2}{*}{ All species $(90)$} & 438 & $48 \pm 12$ & ADF & 0.43 & 8.9 \\
\hline & 438 & & pepsin-cellulase & 0.66 & 6.4 \\
\hline \multirow[t]{2}{*}{ Pterocarpus erinaceus } & 15 & $46 \pm 8$ & ADIN & 0.81 & 3.8 \\
\hline & 15 & & pepsin-cellulase & 0.92 & 2.6 \\
\hline \multirow[t]{2}{*}{ Spondias mombin } & 10 & $47 \pm 4$ & $\mathrm{ADF}$ & 0.70 & 2.5 \\
\hline & 10 & & pepsin-cellulase & 0.75 & 2.3 \\
\hline \multirow[t]{2}{*}{ Daniellia oliveri } & 15 & $42 \pm 8$ & $N$ & 0.96 & 1.7 \\
\hline & & & pepsin-cellulase & 0.80 & 3.6 (n.s) \\
\hline \multirow[t]{2}{*}{ Acacia nilotica } & 13 & $52 \pm 6$ & ADIN & 0.65 & 3.9 \\
\hline & 13 & & pepsin-cellulase & 0.60 & 4.2 \\
\hline
\end{tabular}

"ADF: Acid Detergent Fiber; ADIN: Acid Detergent Insoluble Nitrogen; N: Nitrogen.

rable repeatability and reproducibility, these enzymatic methods allow a satisfactory classification of forages and accurate prediction of in vivo digestibility except for forages containing tannins for which adaptations are necessary.

\section{Nitrogen value prediction}

As shown in Table I, tropical grasses and cereal straws are less rich in total nitrogen than temperate ones. Their digestible nitrogen and rumen nitrogen degradability are also lower. Some shrub and herbaceous legumes behave like lucernes or clovers, while others are poorly digestible. These latter can contain up to $10 \%$ condensed tannins, and often a large proportion of the nitrogen is found in the faeces.

Figure 5. Relationship between apparent digestibility of nitrogen and nitrogen bound in acid detergent insoluble fiber (ADIN) (according to Van Soest, 1994).

Values, obtained from 80 digestion trials with sheep or cattle, are expressed as a percentage of total feed nitrogen. The hays and silages without heat damage $(n=28)$ give a different regression line from forages $(n=52)$ that were heated.
The apparent digestibility of nitrogen was long used to measure the nitrogen value of feeds. However, most of the current methods of evaluation of the nitrogen value recommend taking into account the quantity of proteins absorbed in the small intestine, which corresponds to the quantity of amino acids available to the animal. This implies knowing: (i) The degradability of feed proteins in the rumen, and

(ii) The digestibility of feed proteins in the small intestine.

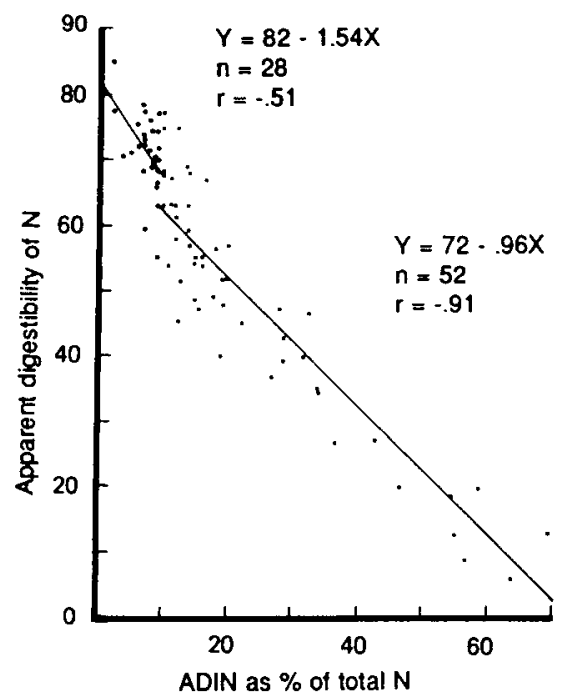




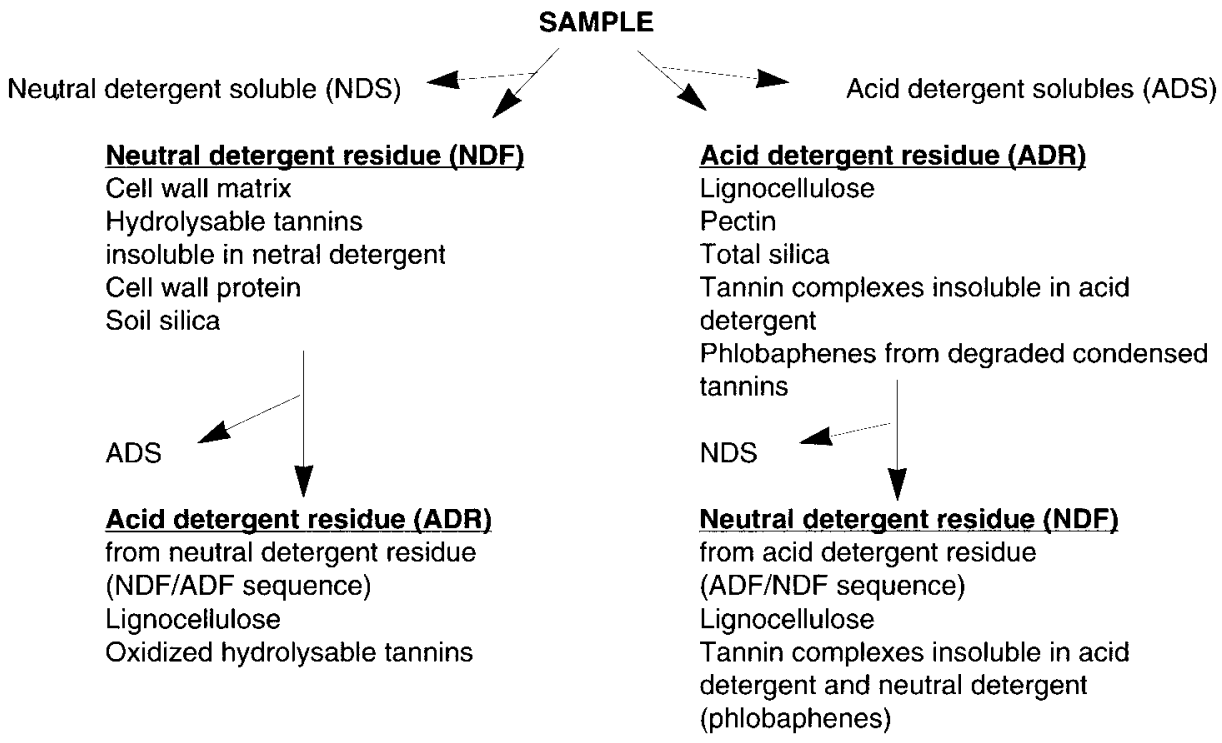

Figure 6. Double sequential analysis from tannins (from Van Soest et al, 1987).

\section{Prediction of digestible crude protein (DCP)}

The true digestibility of forage crude protein is generally very high (about $92-93 \%$ for green forages). The apparent digestibility is lower, because the faeces contain nitrogen-containing substances of endogenous or microbial origin, whose quantities are proportional to the dry matter intake. For this reason, digestible crude protein content (DCP) is closely linked to the total nitrogen content $(C P=N \times 6.25)$ of the forage as expressed by the relation :

$\mathrm{DCP}=\mathrm{CP}-$ in DCP, where inDCP is indigestible crude protein, mainly of endogenous origin.

The inDCP varies slightly, representing 40 to $50 \mathrm{~g}$ per $\mathrm{kg}$ of DM (Demarquilly et al, 1981). The CP in feed that is truly indigestible corresponds essentially to nitrogen linked with ADF (i.e. under $9 \%$ ). The equations are the same for temperate and tropical grasses (Chenost, 1975; Minson, 1982; Richard, 1987).

Conversely, many dicotyledon species, especially woody species, contain proteins that are not readily available since they are enclosed in highly lignified tissues (Koné,
1987; Koné et al, 1989), or complexed with tannins or by Maillard reactions. In all these cases, ADIN is a reliable approach to true indigestible nitrogen and provides a correction to the standard prediction from CP for heated forages (figure 5).

The presence of tannins is also a cause of nitrogen indigestibility, and various scientists have endeavoured to develop methods to predict nitrogen digestibility from the determinations of different phenol fractions (Zimmer, 1993), in particular those that are separated through Van Soest's fractionation: soluble condensed tannins, those dissolved in neutral detergent solution (NDS) and those insoluble either because they precipitate out in the neutral detergent solution or because they remain bound to cell walls (figure 6 ). The NDF/ADF - ADF/NDF sequence provides a first approach to tannin content (Van Soest et al, 1987). The tannins obtained by this method are those linked to the cell walls and proteins, and have marked effects on digestibility.

Although condensed tannins have been shown to play a major role in digestibility, it is still difficult to deduce methods for predicting 
the nitrogen value, or even to classify species in terms of condensed tannin effects. However, condensed tannin content is useful for comparing agroforestry cultivars, since the effects of increasing amounts of condensed tannins has been clearly shown in vivo.

Tannins can also be studied indirectly by their precipitating action (Grillet et Villeneuve, 1994). The methods most often applied use bovine serumalbumin. This method will not separate the beneficial effect of protection against rumen microbes from the negative effects on overall digestibility. It is a simple method for detecting tannins which also act on ingestion by their astringent properties. However, this method, like the chemical determination of tannins, will not predict nitrogen digestibility. Even so, with the help of this method, Robbins et al (1987) set up a model to correct the standard DCP prediction.

Finally, ammonia-treated hays and straws have a noticeably higher in DCP content than the corresponding untreated forages. The faeces of the animals fed with these forages contain, in addition to endogenous and microbial nitrogen, (i) nitrogen from ammonia bound to cell walls and not released in either the rumen or the intestine, (ii) soluble dietary nitrogen derived from $\mathrm{NH}_{3}$ treatment which has not been used by microbes, and (iii) nitrogen from Maillard reactions between nitrogenous constituents and carbohydrates, especially in wet treated hays (Demarquilly and Andrieu, 1987).

\section{Prediction of rumen degradability (Deg)}

In the new nitrogenous systems, it is necessary to know the degradability of nitrogen in the rumen (Deg), which depends on the rate of degradation of the forage in the rumen and the outflow rate of the particles.

\section{By chemical methods (solubility)}

The solubility of proteins in solvents has been abundantly used to estimate protein degradability (Henderickx and Martin, 1963; Johnson, 1976; Wohlt et al, 1976; Crooker et al, 1978; Waldo and Goering, 1979; Vérité et Demarquilly, 1978; Stern and Satter, 1982). However, this solubility varies with the nature of the solvent, its $\mathrm{pH}$ and incubation temperature. The first PDI system (protein digested in the small intestine) (INRA, 1978) relied on measuring nitrogen solubility by the method of Durand (Vérité and Demarquilly, 1978). This measurement characterises the immediately soluble nitrogen fraction. There is a close relationship between in situ degradability and solubility within any given group of feeds (Aufrère et al, 1991), whereas the relations are less clear among different

Table VI. Theoritical fractionation of nitrogen feedstuffs (according to Krishnamoorty et al, 1995).

$\begin{array}{ll}\begin{array}{l}\text { NITROGEN FRACTION } \\ \text { Buffer Soluble } N \\ \text { (borate-phosphate buffer, } \mathrm{pH} 8 \text { ) }\end{array} & \begin{array}{l}\text { NUTRITIONAL PROPERTY } \\ \text { Rapidly degraded in the }\end{array} \\ \begin{array}{l}\text { BIN } \\ \text { in borate phosphate buffer, } \mathrm{pH} 8\end{array} & \text { Slowly degraded in the rum } \\ \begin{array}{l}\text { PSN } \\ \text { (extracted from Streptomyces griseus) } \\ \text { in borate phosphate buffer, } \mathrm{pH} 8\end{array} & \text { Total N Degraded in the } \\ \text { PIN } & \\ \text { PIN - ADIN }= & \text { Rumen undegraded N } \\ \text { ADIN } & \begin{array}{l}\text { Rumen undegraded but } \\ \text { digestible in intestin N }\end{array} \\ \end{array}$

PSN: Protease Soluble N; BIN: Buffer Insoluble N; PIN: Protease Insoluble N; ADIN: Acid Detergent Insoluble N. 
groups and in mixed feeds.

These solubility measurements have been gradually abandoned in favour of enzymatic methods, since they fail to take into account the slowly degradable protein fraction in the rumen.

\section{By enzymatic methods}

These methods use poorly specific commercial proteases, of bacterial, plant, animal or fungal origin (Aufrère and Michalet-Doreau, 1990). They have mainly been tested on concentrates (Pichard and Van Soest, 1977; Chamberlain and Thomas, 1979; Poos-Floyd et al, 1985; Aufrère et al, 1991; Susmel et al, 1989) and temperate forages (Aufrère et al, 1989), but rarely on roughages. They are inexpensive compared to the reference methods (measurements in nylon bags), and offer the following advantages: there is neither microbial contamination of bag residues, nor loss of particles through the bag mesh.

Although set values of Deg were proposed in 1988 for each major type of forage, the nitrogen degradability of green forages in temperate countries varies according to the growth stage, species and season (LeGoffe et al, 1993; Amrane and Michalet-Doreau 1993). The Deg can be predicted accurately from the nitrogen content and by measuring the quantity of protease solubilised after one hour (Aufrère and Cartailler, 1988).

The application of these methods to forages containing tannins raises certain problems.

(i) In the method selected by Aufrère et al (1991), the commercial protease, of bacterial origin, is used in a borate-phosphate buffer at $\mathrm{pH}$ 8. At this $\mathrm{pH}$ the enzyme activity is optimum, but the tannin-protein complexes are unstable, which may cause an overestimation of the true enzyme degradability. Other methods use lower $\mathrm{pH}$ values between 5.5 and 7 (Assoumani et al, 1992), but have seldom been tested on forages.

(ii) In in vitro studies, some authors (Tagari et al, 1965; Oh and Hoff, 1988) have shown an inhibiting effect of tannins on the activities of proteolytic enzymes, which might distort the results obtained with enzyme methods using proteases.

However, for tree foliage rich in tannins, the enzymatic method enables the accurate ranking of species and organs and can be used for screening (Zoungrana, 1995).

\section{Prediction of intestinal digestibility (dr)}

Determination of true digestibility in the intestine (dr) requires knowing the quantity of dietary nitrogen that has escaped degradation in the rumen and is truly indigestible in the small intestine (PIAnd).

In the French system, these PIAnd values are estimated from inDCP values minus faecal nitrogen of microbial and endogenous origin. In other systems, PIAnd values are estimated from nitrogen remaining in the bags after a long period in the rumen or from ADIN considered as indigestible. Enzymatic methods (pepsin-pancreatin) applied to samples after rumen digestion provide a good estimation of intestinal digestibility for concentrate feeds (Antoniewicz et al, 1992; Calsamiglia and Stern, 1995). In contrast, for forages, Van Straalen et al (1993) found a lower indigestible protein content with the mobile bag method than with the pepsin-pancreatin method.

If little work has been done on $d r$ measurement for temperate forages, even less has been done on tropical forages (except for Mgheni et al, 1994), even though the $d r$ is certainly highly variable for forages rich in tannins since the tannin-protein bonds can be partly hydrolysed in the intestine.

The methods that have become most commonly used for nitrogen degradability measurements in roughages are those that take into account cell wall constituents as indicated by the very accurate prediction (RSD $=3.6, R^{2}=0.98$ ) obtained between Deg and ADIN on tropical shrubs by Fall-Touré and Michalet-Doreau, (1995). Recently, Krisnamoorthy et al (1995) have presented a more elaborate model to predict nitrogen degradability of tropical by-products, taking into account both degradation in a protease at $\mathrm{pH} 8$ and nitrogen bound to NDF (NDIN) and ADF residues (table VI). This model, which is still being developed, takes into account the degradability of nitrogen, limited by whether cell wall tannins or heating.

\section{Conclusion}

The nutritive value of roughages (tropical forages, crop residues and especially tree foliage) is often predicted with less accuracy than that of temperate forages, even if its variability is as wide. This is partly due to the 
botanical heterogeneity of the samples. Moreover, the methods for predicting the nutritive value have almost all been developed using samples of temperate zone forages. They are often applied to tropical forages without making the necessary adaptations to allow for the specific physical and chemical features of plants growing in tropical climates.

Van Soest's fractionation, despite its imperfections, is still a useful and global method for measuring the energy value, while NDIN and ADIN offer a first approach to the mechanisms of nitrogen degradation in the rumen and intestine.

Enzymatic methods can find important applications in laboratory analyse to predict the nutritive value of roughages. They are inexpensive relative to the reference in vivo methods, and are also faster and easier to implement routinely. They are generally accurate, repeatable and reproducible, but need to be calibrated against samples measured in vivo. When applied to tropical zone forages containing neither tannins nor anti-nutritional substances, the accuracy of the prediction of energy value is close to that obtained for temperate zone forages. The prediction of the nitrogen value with proteolytic enzymes has been less studied for temperate and tropical forages. The use of commercially available enzymes at their optimal $\mathrm{pH}$ rather than at rumen $\mathrm{pH}$ raises problems. The values obtained will be distorted if tannin-protein complexes are hydrolysed, and the commercial enzymes may be inhibited to some extent by tannins. At present it is difficult to predict the nutritive value of forages, especially woody forages, on the basis of their tannin content. In the future, reliable methods for predicting the nutritive value of forages taking into account the tannin content have thus to be developed.

\section{Literature cited}

Ahn $\mathrm{JH}$, Robertson BM, Elliot $\mathrm{A}$, Gutteridge RC, Ford CW (1989) Quality assessment of tropical browse legumes: tannin content and protein degradation. Anim Feed Sci Technol 27, 147-156

Aii T, Stobbs TH (1980) Solubility of the protein of tropical pasture species and the rate of its digestion in the rumen. Anim Feed Sci Technol 5 , 183-192

Alberts B, Bray D, Lewis J, Raff M, Roberts K, Watson DJ (1989) Biologie moléculaire de la cellule. 2 e édition. Flammarion, Paris, $1217 \mathrm{p}$
Amrane R, Michalet-Doreau B (1993) Effect of maturity stage of Italian rye grass and lucerne on ruminal nitrogen degradability. Ann Zootech 42, 31-37

Andrieu J, Weiss Ph (1981) Prévision de la digestibilité et de la valeur énergétique des fourrages verts de graminées et de légumineuses. In: Prévision de la valeur nutritive des aliments pour les ruminants (INRA, ed) Versailles, France, 61-79.

Antoniewicz AM, Van Vuren AM, Van der Koelen CJ, Kosmala I (1992) Intestinal digestibility of rumen undegraded protein of formaldehyde-treated feedstuffs measured by mobile bag and in vitro technique. Anim Feed Sci Technol 39, 111-124

Assoumani MB, Vedeau F, Jacquot L, Sniffen CJ (1992) Refinement of an enzymatic method for estimating the theoretical degradability of proteins in feedstuffs for ruminants. Anim Feed Sci Technol 39, 357-368

Aufrère J, Cartailler D (1988) Mise au point d'une méthode de laboratoire de prévision de la dégradabilité des protéines alimentaires des aliments concentrés dans le rumen. Ann Zootech $37,255-270$

Aufrère J, Michalet-Doreau B, Graviou D, Vérité R (1989) Predicting in sacco degradability of hay protein by chemical or enzymatic methods. $X V I$ Intern Grassi Congr Nice, France, 2, 887-889

Aufrère J, Demarquilly C (1989) Predicting organic matter digestibility of forage by two pepsincellulase methods. XVI Intern Grass/ Congr Nice, France, 2, 877-879

Aufrère J, Michalet-Doreau B (1990) Nouvelles methodes d'estimation de la valeur alimentaire des fourrages. II. Méthodes enzymatiques. Fourrages $42,120-121$

Aufrère J, Graviou D, Demarquilly C, Vérité R, Michalet-Doreau B, Chapoutot P (1991) Predicting in situ degradability of feed proteins in the rumen by two laboratory methods (solubility and enzymatic degradation). Anim Feed Sci Techno/ 33, 97-116

Barry TN, Manley TR, Duncan SJ (1986) The role of condensed tannins in the nutritional value of Lotus pedunculatus for sheep. 4. Sites of carbohydrate and protein digestion as influenced by dietary reactive tannin concentration. $\mathrm{Br} J \mathrm{Nutr}$ 55, 123-137

Calsamiglia S, Stern MD (1995) A three-step in vitro procedure for estimating intestinal digestion of protein in ruminants. J Anim Sci 73, 1459-1465

Chamberlain DG, Thomas PC (1979) Prospective laboratory methods for estimating the susceptibility of feed proteins to microbial breakdown in the rumen. Proc Nutr Soc 38, 138A

Chenost M (1975) La valeur alimentaire du Pangola (Digitaria decumbens Stent.) et ses facteurs de 
variation en zone tropicale humide. Ann Zootech $24,327-349$

Conklin NL, Horvath P J, Van Soest PJ, McDowel RE (1987) Predicting the digestibility of tropical browse. J Anim Sci 5, 1, 347

Crooker BA, Sniffen CJ, Hoover WH, Johnson LL (1978) Solvents for soluble nitrogen measurements in feedstuffs. J Dairy Sci 61 , 437-447

Demarquilly C, Chenost M (1969) Etude de la digestion des fourrages dans le rumen par la méthode des sachets de nylon; liaisons avec la valeur alimentaire. Ann Zootech 18, 419-436

Demarquilly C, Jarrige R (1981) Panorama des méthodes de prévision de la digestibilité et de la valeur énergétique des fourrages. XI Journées du Grenier de Theix. In : Prévision de la valeur nutritive des aliments des ruminants (INRA, ed) Versailles, France, 41-59

Demarquilly C, Grenet E, Andrieu J (1981) Les constituants azotés des fourrages et la prévision de la valeur azotée des fourrages. (INRA, ed) Versailles, France, 129-154

Demarquilly C, Andrieu J (1987) Prévision de la valeur alimentaire des fourrages secs au laboratoire. In : Les fourrages secs : récolte, traitement, utilisation (C Demarquilly, ed) Paris, 243-275

D'Mello JPF (1992) Chemical constraints to the use of tropical legumes in animal nutrition. Anim Feed Sci Technol 38, 237-261

Donefer E, Niemann PJ, Crampton EW, Llyod LE (1963) Dry matter disappearance by enzyme and aqueous solutions to predict the nutritive value of forages. J Dairy Sci $46,965-970$

Fall-Touré S, Michalet-Doreau B (1995) Nitrogen partition in cell structures of tropical browse plants compared with temperate forages: influence on their in situ degradation pattern. Anim Feed Sci Technol 51, 65-72

Giger-Reverdin S (1995) Review of the main methods of cell wall estimation: interest and limits for ruminants. Anim Feed Sci Technol 55, 295-334

Goering HK, Van Soest PJ (1970) Forage fiber analyses (apparatus, reagents, procedures and some applications). Agriculture Handbook United States Department of Agriculture, 279, 1-20

Goto L, Minson DJ (1977) Prediction of the dry matter digestibility of tropical grasses using a pepsincellulase assay. Anim Feed Sci Technol 2, 247 253

Grillet C, Villeneuve F (1994) Les tanins dans les fourrages ligneux consommés par les ruminants en Afrique centrale et de l'ouest. Commission des Communautés Européennes DG XII, Programme ST2/89/215 Maisons-Alfort, CIRADEMVT
Guérin H (1987) Alimentation des ruminants domestiques sur pâturages naturels sahéliens et sahélo-soudaniens : étude méthodologique dans la région de Ferlo au Sénégal. Thèse Doct Ing. Montpellier, ENSAM, 213p

Guérin $H$, Richard $D$, Friot $D$, Mbaye $N$, Koné AR (1988) Intérêt du dosage de la lignocellulose (ADF) et de différentes fractions azotées pour prévoir la valeur nutritive des fourrages naturels sahéliens. Reprod Nutr Dév 28, 1, 111-112

Guérin $H$, Richard $D$, Lefevre $P$, Friot $D$, Mbaye $N$ (1989) Prévision de la valeur nutritive des fourrages ingérés sur parcours naturels par les ruminants domestiques sahéliens et soudaniens. XVI Intern Grass/ Congr Nice, France, 2, 879-880

Guillermin P, Cordesse R, Dulphy JP (1988) Prévision de la digestibilité des pailles et des foins de graminées traités ou non à l'ammoniac à partir des mesures de laboratoire. Ann Zootech 37 (1), 43-56

Hatfield RD (1992) Carbohydrate composition of alfalfa cell walls isolated from stem sections differing in maturity. $J$ Agric Food Chem $40,424-$ 430

Henderickx H. Martin J (1963) In vivo study of the nitrogen metabolism in the rumen. $\mathrm{CR}$ Rech $\mathrm{Sci}$ Ind Agric, Bruxelles, 31, 1-66

Huffaker RC (1982) Biochemistry and physiology of leaf proteins. In: Nucleic acids and proteins in plants: Encyclopaedia of Plant Physio (D Boulter, B Parthier, eds) Springer Verlag Berlin, $14 \mathrm{~A}$ $370-400$

INRA (1978) Alimentation des ruminants. Principe de la nutrition et de l'alimentation, des ruminants. Besoin alimentaire des animaux. Valeur nutritive des aliments. (R Jarrige, ed) INRA Publ, Versailles, France.

INRA (1989) Ruminant Nutrition. Recommended allowances. Feeds and Tables. (R Jarrige, ed) John Libbey Eurotext, Paris, London, Rome

Jarrige R (1961) Analyse des constituants glucidiques des plantes fourragères. Ann Biol anim Bioch Biophys 1, 163-202

Jarrige R, Thivend P (1969) Action d'une cellulase fongique sur les membranes et son intérêt pour prévoir la digestibilité des plantes fourragères. Ann Biol anim Biochim Biophys 9, 171-190

Johnson RR (1976) Influence of carbohydrate solubility on non protein nitrogen utilization in the ruminant. J Anim Sci 43, 184-191.

Jones WT, Mangan JL (1977) Complexes of the condensed tannins of sainfoin (Onobrychis viciifolia Scop.) with fraction: I Leaf protein and with submaxillary mucoprotein, and their reversal by polyethylene glycol and $\mathrm{pH}$. J Sci Fd Agric 28, 126-136

Koné AR (1987) Valeur nutritive des ligneux 
fourragers des régions sahéliennes et soudaniennes d'Afrique occidentale : recherche d'une méthode simple d'estimation de la digestibilité et de la valeur azotée. Thèse $3 \mathrm{e}$ cycle, Univ Paris VI, IEMVT, $205 p$

Koné AR, Richard D, Guérin H (1989) Teneurs en constituants pariétaux et en matières azotées des ligneux fourragers d'Afrique occidentale. XVI Intern Grass/ Congr Nice, France, 2, 947-948

Krishnamoorthy $\mathrm{U}$, Soller $\mathrm{H}$. Steingass $\mathrm{H}$, Menke $\mathrm{KH}$ (1995) Energy and protein evaluation of tropical feedstuffs for whole tract and ruminal digestion by chemical analyses and rumen inoculum studies in vitro. Anim Feed Sci Technol 52, 177 188

Kronauer M, Bickel $H$ (1981) Estimation of the energy value of East African pasture grass. In: 32th animal meeting of the European Association for Animal Production, Zagreb, Yugoslavia, $6 p$

Lapierre C, Jouin D, Monties B (1989) On the molecular origin of the alkali solubility of Gramineae lignins. Phytochemistry 28, 1401 1403

Le Goffe P, Vérité R. Faverdin P (1993) Facteurs de variation et prédiction de la dégradabilité de l'azote des fourrages verts dans le rumen. Ann Zootech 42, 17-29

Makkar HPS, Borowy NK, Becker K, Degen A (1995) Some problems in fiber determination of a tanninrich forage (Acacia saligna leaves) and their implications in in vivo studies. Anim Feed Sci Technol 55, 67-76

Mandels M, Reese ET (1963) Inhibition of cellulases and beta-glucosidases. In: Advances in enzymatic hydrolysis of cellulose and related materials. (ET Reese, ed) MacMillan, New-York, 115-158

Mangan JL (1988) Nutritional effects of tannins in animal feeds. Nutr Res Reviews 1, 209-231

Manidool C (1983) Leucaena leaf meal and forage in Thailand. In: Leucaena research in the Asian Pacific region International Development Research Centre, Ottawa, Canada, 65-72

Mc Leod MN (1974) Plant tannins-their role in forage quality. Nutr Abstr Rev 44, 803-815

Menke KH, Raab L, Salewski A, Steingass H, Fritz D, Schneider $W(1979)$ The estimation of the digestibility and metabolizable energy content of ruminant feedingstuffs from the gas production when they are incubated with rumen liquor in vitro. J Agric Sci 93, 217-222

Mgheni DM, Hvelplund T, Weisbjerg MR (1994) Intestinal digestibility of rumen undegraded dietary protein from tropical roughages estimated by the mobile bag technique. Acta Agric Scand Sect A, Anim Sci 44, 230-235

Minson DJ (1982) Effect of chemical composition on feed digestibility and metabolizable energy. Nutr Abstr Rev B, 592-615

Moore KJ, Hatfield RD (1994) Carbohydrates and Forage quality. In: Forage quality, Evaluation and Utilization. National Conference at the University of Nebraska (C Fahey, M Collins, DR Mertens, LE Moser, eds) Lincoln, 229-281

Navaratne HVRG, Ibrahim MNM, Schiere JB (1990) Comparison of four techniques for predicting digestibility of tropical feeds. Anim Feed Sci Technol 29, 209-221

Oh HI, Hoff JE (1988) Interaction of condensed grape tannins with pepsin and trypsin in simulated human digestive system. Nut Rep /nt 38,445-453

Pichard G, Van Soest PJ (1977) Protein solubility of ruminant feeds. Proc Cornell Nutri Conf, Cornell Nutrition Conference for Feed Manufacturers, Syracuse, NY, 91-98

Poos-Floyd M, Klopfenstein T, Britton RA, Olson DG (1985) Evaluation of laboratory techniques for predicting ruminal protein degradation. $J$ Dairy Sci $68,829-839$

Redfearn DD, Moser LE, Waller SS, Klopfenstein TJ (1995) Ruminal degradation of switchgrass, big bluestern, and smooth bromegrass leaf proteins. $J$ Anim Sci 73, 598-605

Reed JD (1995) Nutritional toxicology of tannins and related polyphenols in forage legumes. $J$ Anim Sci 73, 1516-1528

Rexen B (1977) Enzyme solubility - a method for evaluating the digestibility of alkali-treated straw. Anim Feed Sci Technol 2, 205-218

Richard D (1987) Intérêt de la connaissance de la composition chimique des fourrages. Choix des analyses en fonction des objectifs. Actes du séminaire régional sur les fourrages et l'alimentation des ruminants. N'Gaoundéré, Cameroun, Etudes et synthèses de I'IEMVT, Maisons Alfort,30, 695-626

Richard D, Guerin H, Fall Touré S (1989) Feeds of the dry tropics (Sénégal). In: Ruminant Nutrition. Recommended allowances. Feeds Tables. ( $R$ Jarrige, ed), INRA Paris, John Libbey Eurotext, Paris, London, Rome, 325-342

Robbins CT, Mole S, Hagerman AE, Hanley TA (1987) Role of tannins in defending plants against ruminants reduction in dry matter digestion. Ecology 68, 1606-1615

Scehovic J (1990) Tanins et autres polymères phénoliques dans les plantes de prairies: détermination de leur teneur et de leur activité biologique. Revue Suisse Agric 22, 179-184

Silva Colomer JS, Zarate M, Guevara JC, Frasinelli C (1989) Enzymatic solubility and other analytic parameters predicting digestibility in grasses of middling food value. In: XVIth int Grass/ Congr, Nice, II, 909-910 
Smart WWG, Bell TA, Stanley NW, Cope WA (1961) Inhibition of rumen cellulase by an extract from sericea forage. J Dairy Sci 44, 1945-1946

Steingass H, Arbelot B (1994) In vitro studies for the prediction of digestibility, metabolisable energy content and protein fermentability of shrub and tree fodders. In: Valeur alimentaire des fourrages ligneux consommés par les ruminants en Afrique centrale et occidentale, CCE-DGXII ST2.A, 89/215.F, 1-58

Stern MD, Satter LD (1982) In vivo estimation of protein degradability in the rumen. $I n$ : Protein Requirements for Cattle (NE Owens, ed) Symposium, Oklaoma State Univ, Stillwater, OK, 57

Susmell P, Stefanon B, Mills CR, Colliti M (1989) The evaluation of PDI concentrations in some ruminant feedstuffs: a comparison of in situ and in vitro protein degradability. Ann Zootech 38, 209-232

Tagari H, Henis Y, Tamir M, Volcani R (1965) Effect of carob pod extract on cellulolysis, proteolysis, deamination, and protein biosynthesis in an artificial rumen. App/Microbiol 13, 437-442

Tilley JM, Terry RA (1963) A two-stage technique for in vitro digestion of forage. $\mathrm{JBr}$ Grass Soc 18 , 104-111

Terry RA, Mundell DC, Osbourn DF (1978) Comparison of two in vitro procedures using rumen liquor-pepsin or pepsin-cellulase for prediction of forage digestibility. $\mathrm{J} B r$ Grass $/$ Soc $33,13-18$

Van Soest PJ (1964) symposium of nutrition and forage and pastures: new chemical procedures for evaluating forages. J Anim Sci 23, 838-845

Van Soest PJ (1967) Development of a comprehensive system of feed analysis and its application to forages. J Anim Sci 26, 119-128

Van Soest PJ, Wine RH (1967) Use of detergents in the analysis of fibrous feeds. IV Determination of plant cell-wall constituents. J Assoc Off Agric Chem 50, 50-55

Van Soest PJ, Robertson JB (1980) Systems of analysis for evaluating fibrous feeds. Standardization of analytical methodology for feeds. In: Proc Int Dev Res Center (WJ Pigden,
CC Balch, Graham, eds) IDRC 134 ed, Ottawa, Canada, 49-60

Van Soest PJ (1982) Nutritional ecology of the ruminant. O B Books Inc Corvallis, Oregon, 373p

Van Soest PJ, Conklin NL, Horvarth PJ (1987) Tannins in foods and feeds. In: Proc Cornell Nutr Conf, Ithaca, New York., 127-135

Van Soest PJ, Mason VC (1991) The influence of the Maillard reaction upon the nutritive value of fibrous feeds. Anim Feed Sci Technol 32, 45-53

Van Soest PJ (1994) Nutritional ecology of the ruminant, 2nd edition. Cornell Univ Press, 476p

Van Straalen WM, Dooper FMH, Antoniewicz AM, Kosmala I, Van Vuuren AM (1993) Intestinal digestibility in dairy cows of protein from grass and clover measured with mobile nylon bag and other methods. J Dairy Sci 76, 2970-2981

Vérité R, Demarquilly C (1978) Qualités des matières azotées des aliments pour ruminants. $I n: L a$ Vache laitière. INRA, Versailles, 143-147

Waldo DR, Goering HK (1979) Insolubility of proteins in ruminant feeds by four methods. $J$ Anim SCi 49. 1560-1568

Wilson JR, Brown RH, Windham WR (1983) Influence of leaf anatomy on the dry matter digestibility of $\mathrm{C}_{3}, \mathrm{C}_{4}$ and $\mathrm{C}_{3} / \mathrm{C}_{4}$ intermediate types of Panicum species. Crop Sci 23, 141-146

Wilson JR (1994) Cell wall characteristics in relation to forage digestion by ruminants (review). J Agric Sci, Camb, 122, 173-182

Wohlt JE, Sniffen CJ, Hoover WH, Johnson LL, Walker CK (1976) Nitrogen metabolism in wethers as affected by dietary protein solubility and amino acid profiles. I Anim Sci 42, 12801289

Zimmer N (1993) Dosage des polyphénols. In: Evaluation des ressources fourragères locales dans les régions méditerranéennes Thessalonique, Grèce, $15 p$

Zoungrana $C$ (1995) Composition chimique et valeur nutritive des herbacées et ligneux des pâturages naturels soudaniens et des sous-produits du Burkina Faso. Thèse d'Etat Univ Ouagadougou, $224 p$ 